\title{
Homologous illegitimate random integration of foreign DNA into the $X$ chromosome of a transgenic mouse line
}

\author{
Bowen Yan ${ }^{1}$, Defa Li ${ }^{2}$, Kemian Gou ${ }^{1 *}$
}

\begin{abstract}
Background: It is not clear how foreign DNA molecules insert into the host genome. Recently, we have produced transgenic mice to investigate the role of the fad 2 gene in the conversion of oleic acid to linoleic acid. Here we describe an integration mechanism of fad 2 transgene by homologous illegitimate random integration.

Results: We confirmed that one fad2 line had a sole integration site on the $X$ chromosome according to the inheritance patterns. Mapping of insertion sequences with thermal asymmetric interlaced and conventional PCR revealed that the foreign DNA was inserted into the XC1 region of the $\mathrm{X}$ chromosome by a homologous illegitimate replacement of an entire 45,556-bp endogenous genomic region, including the ovarian granulosa cell tumourigenesis-4 allele. For $5^{\prime}$ and $3^{\prime}$ junction sequences, there were very short (3-7 bp) common sequences in the AT-rich domains, which may mediate the recognition of the homologous arms between the transgene and the host genome. In addition, analysis of gene transcription indicated that the transgene was expressed in all tested fad 2 tissues and that its transcription level in homozygous female tissues was about twice as high as in the heterozygous female $(p<0.05)$.

Conclusions: Taken together, the results indicated that the foreign fad2 behaved like an X-linked gene and that foreign DNA molecules were inserted into the eukaryotic genome through a homologous illegitimate random integration.
\end{abstract}

\section{Background}

Direct microinjection of foreign DNA into the pronucleus of fertilised zygotes is a conventional method to generate transgenic animals, whereas the exact integration site and the number of copies of the transgene are random and unpredictable [1,2]. Previous studies involving animal transgenesis indicate that the linear DNA molecules injected into the pronucleus undergo rapid circularisation followed by random linearisation and concatemer formation by homologous recombination before integration into the host genome [3-5]. It was thought that the foreign DNA concatemers would be finally inserted into the host DNA randomly through imperfect sequence recognition via heterologous recombination followed by cellular DNA repair activity $[2,6]$.

\footnotetext{
* Correspondence: goukm@cau.edu.cn

'State Key Laboratory for Agrobiotechnology, College of Biological Sciences, China Agricultural University, Beijing 100193, China

Full list of author information is available at the end of the article
}

Until now, it was not clear how foreign DNA molecules insert into the host genome. A few studies have unravelled some of the mystery of random integration and indicated that the integration site of foreign DNA is not totally random [6,7]. More detailed analyses of the integration sites revealed some interesting trends. For instance, a review of 35 different insertion mutants generated in transgenic mouse lines revealed that some chromosomes, such as chromosome 10 and 6, are selected more often for illegitimate integration than others [8]. Intrinsic DNA structures such as bent DNA elements could be a major determinant in chromosomal illegitimate recombination because their structure can provide a preferential donor site for the integration $[9,10]$. In addition, short identical sequences of 1 to 3 nucleotides have been found at the genome-transgene junctions [11]. These integration sites are usually associated with the consensus sequence for topoisomerase-I cleavage sites [11,12].
C Biomed Central

() 2010 Yan et al; licensee BioMed Central Ltd. This is an Open Access article distributed under the terms of the Creative Commons Attribution License (http://creativecommons.org/licenses/by/2.0), which permits unrestricted use, distribution, and reproduction in any medium, provided the original work is properly cited. 
Recently, we have successfully used standard pronuclear microinjection to produce transgenic mice integrated with the fad 2 gene from the cotton plant, encoding fatty acid desaturase-2. Those transgenic mice were used to study the role of FAD2 in the conversion of oleic acid to linoleic acid. In the present study, using the transgene inheritance pattern of F1 progeny, we showed that one of the transgenic lines had only one integration site on the $\mathrm{X}$ chromosome. Thermal asymmetric interlaced PCR (TAIL-PCR) $[13,14]$ was used to identify the transgenechromosome junction in mice previously [15-17]. To investigate the exact insertion site on the $\mathrm{X}$ chromosome, this method was also employed to map the 3' chromosomal boundaries of the integration site in fad 2 mice. We successfully defined the $3^{\prime}$ integration site by TAIL-PCR and the $5^{\prime}$ integration site by conventional PCR. Based on the sequence data of both junctions, the mechanism of the homologous illegitimate random integration of the foreign DNA in transgenic animals was also analysed. Finally, the transcription characteristics of the X-linked fad2 were investigated further.

\section{Results}

\section{Analysis of transgene inheritance}

PCR (Figure 1A) and Southern blotting analysis (Figure 1B) demonstrated that a male mouse (mouse-1) integrated the foreign gene. PCR analysis of its F1 offspring produced by seven C57 females showed that all 23 heterogeneous males were nontransgenic, whereas all 27 heterogeneous females were transgenic (Figure 1C). The results indicated that the $\mathrm{fad} 2$ transgene integrated into the X chromosome.

\section{Identity of the $3^{\prime}$ integration site}

To determine the integration site of the foreign DNA on the $\mathrm{X}$ chromosome, TAIL-PCR was used to define the $3^{\prime}$ chromosomal boundaries of the transgene (Figure 2A). Each PCR fragment, amplified by the tertiary cycling from the samples of three mouse-1 progeny, was purified and sequenced directly (Figure 2B). Sequencing and BLAST search results in the Mus musculus (C57BL/6J) genome showed that the mouse-15 fragments were derived from the transgene itself, whereas PCR products of mouse- 3 and mouse- 5 contained both the foreign DNA and the X flanking sequences (Figure 2C). Homology analysis indicated that the foreign gene was integrated into the $\mathrm{XC1}$ region and that the junction site was located at base 87,507,732.

Junction sequence analysis also showed that there was an additional 29-bp fragment (Figure 2C, from -22 to +7 ) between the $3^{\prime}$ end of the transgene and the $\mathrm{X}$ flanking sequence. This 29-bp sequence was $100 \%$ identical to the initial $5^{\prime}$-end of the foreign DNA in which the last seven nucleotides ( $5^{\prime}$-ttaatag-3', Figure $2 \mathrm{C}$, from

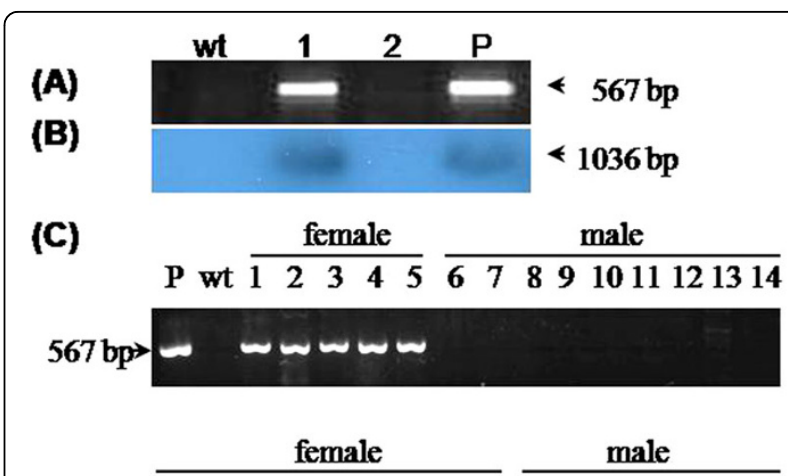

wtP M 1516171819202122232425262728293031
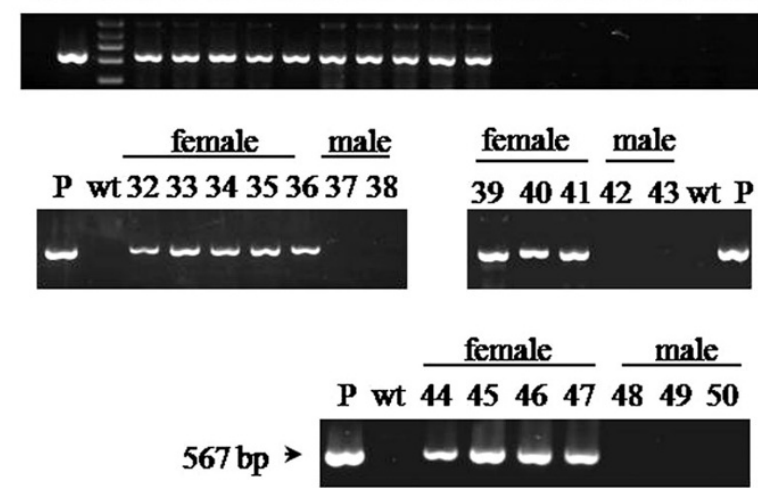

Figure 1 Transgene analysis. (A) PCR and (B) Southern blot analysis of total DNA from wild-type C57 (wt), mouse-1 (lane 1) and mouse-2 (lane 2) shows that mouse- 1 was fad 2 transgenic, whereas mouse-2 was nontransgenic. $P$, the mixture of fad 2 plasmid and wt genomic DNA (A) or the 1036-bp fragments of fad2 transgene digested by EcoR I and Sca I enzymes together (B). (C) PCR analysis of total DNA from 50 heterogeneous F1 mice produced by natural mating of the $\mathrm{C} 57$ females and mouse-1 (male) show that all $27 \mathrm{~F} 1$ females (mice nos. 1-5, 15-24, 32-36, 39-41, and 44-47) were transgenic, whereas all 23 F1 males (mice nos. 6-14, 25-31, 37-38, 42-43, and 48-50) were nontransgenic. M, DNA marker. $P$, the mixture of fad2 plasmid and wt genomic DNA.

+1 to +7 ) were also shared by the $\mathrm{X}$ chromosome sequence. Additional PCR amplification using the specific primers that spanned the above junction sequence confirmed that the 3 ' integration site (data not shown) was successfully mapped. These results suggest that the transgene integration was mediated by the seven common nucleotides.

\section{Identity of heterozygotes}

Genotypes were determined by PCR amplification using transgene-specific (567-bp) and genome-specific primer (495-bp) sets concurrently. As shown in Figure 3, amplification of the heterozygous transgenic DNA in the $\mathrm{X}^{+} \mathrm{X}$ female sample resulted in two bands, 567 bp and 495 bp. C57 DNA yielded only a single 495-bp band, and homozygous transgenic DNA in the $\mathrm{X}^{+} \mathrm{X}^{+}$female or the $\mathrm{X}^{+} \mathrm{Y}$ male yielded only a $567-\mathrm{bp}$ band. 


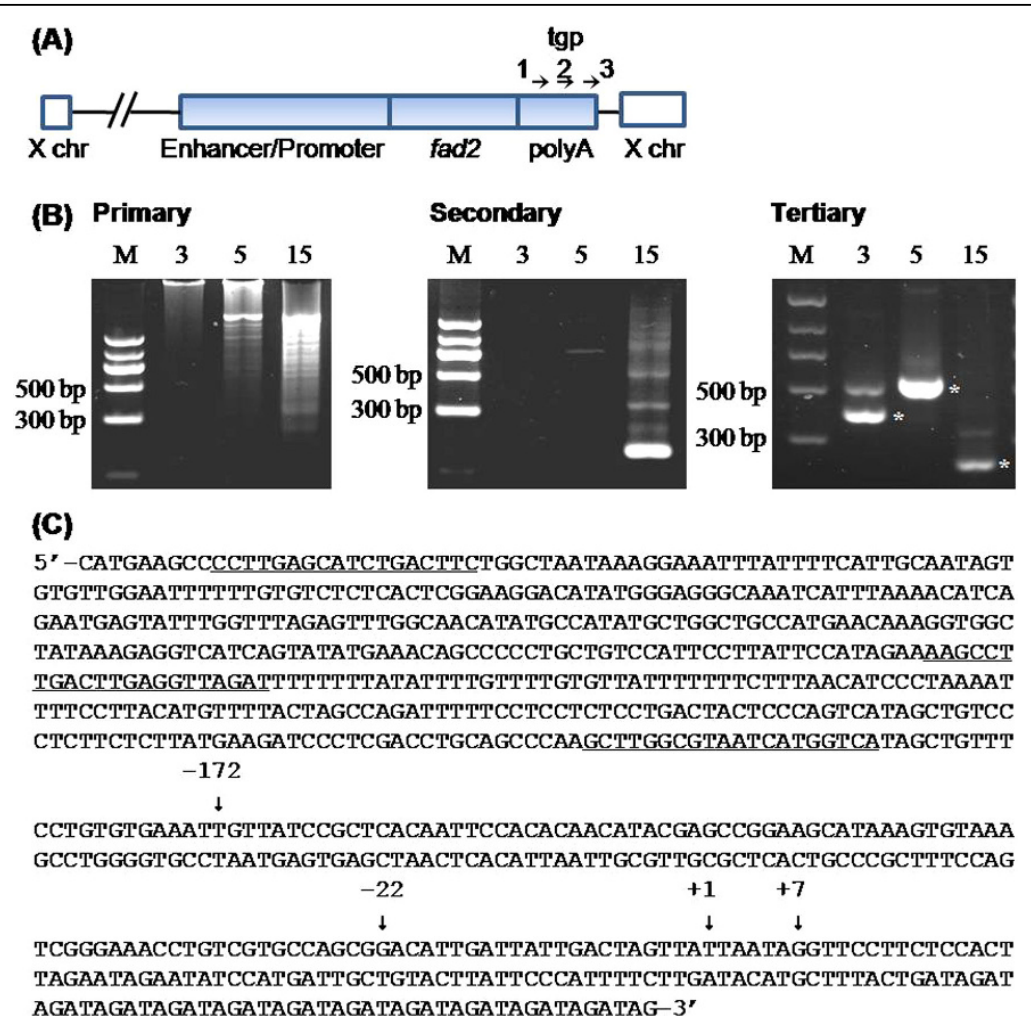

Figure 2 TAIL-PCR analysis of the $\mathbf{3}^{\prime}$ integration site. (A) Schematic diagram of the transgenic construct indicating the positions of three transgene primers (tgp) used, along with an arbitrary degenerate primer. (B) Gel analysis of TAlL-PCR products amplified from the fad2 mice. Total DNA from three fad2 mice (nos. 3, 5, and 15) was used for TAIL-PCR, and the specific amplified fragments $\left(^{*}\right.$ ) in each sample from the tertiary amplification were sequenced directly. (C) Nucleotide sequence of transgenic forward primers (underlined) tgp1 (-627 to -610), tgp2 (-381 to -360$)$, and tgp3 (-206 to -187) and the $3^{\prime}$ integration region in fad2 mice. The sequence from -172 to the $3^{\prime}$ end was determined by direct sequencing. The sequencing results indicate that nucleotides from -172 to +7 were $100 \%$ identical to the transgene sequences and that the nucleotides from +1 to the $3^{\prime}$ end were the same as the downstream sequence of the 87,507,732nd nucleotide of the XC1 region of the $X$ chromosome. Seven nucleotides, from +1 to $+7\left(5^{\prime}-T\right.$ TAATAG- $\left.3^{\prime}\right)$, were shared by the transgene and the $X$ chromosome as a very short homologous arm. Furthermore, the sequences from -172 to -22 and -22 to +7 , corresponding to the $3^{\prime}$ end and the $5^{\prime}$ initial transgene sequences, indicate that the foreign DNA molecules integrated as a head-to-tail array.

\section{Identity of the $5^{\prime}$ integration site}

Based on the $3^{\prime}$ integration site at $87,507,732$, several primer sets corresponding to its known upstream sequence (GenBank accession no. NT_039706.7) were designed to map the $5^{\prime}$ integration position. Among them, the results of three amplifications are shown in Figure 4. P1 primers, corresponding to the $-54,088$ to $-53,884$ region, successfully amplified the 205-bp fragment in all of the $\mathrm{X}^{+} \mathrm{X}^{+}, \mathrm{X}^{+} \mathrm{X}, \mathrm{X}^{+} \mathrm{Y}$ and $\mathrm{C} 57$ samples. P2 and $\mathrm{P} 3$ primers, corresponding to regions $-29,872$ to $-29,553$ and $-44,562$ to $-44,144$, respectively, only amplified the 320-bp and 419-bp fragments, respectively, in X ${ }^{+} \mathrm{X}$ and $\mathrm{C} 57$, but not in the $\mathrm{X}^{+} \mathrm{X}^{+}$or $\mathrm{X}^{+} \mathrm{Y}$ samples (Figure 4B). These results indicate that the $5^{\prime}$-integration site was within the $-53,884$ to $-44,562$ region.

Further PCR analysis was performed using several additional primer sets consisting of the forward primers, corresponding to X loci from $-53,884$ to $-44,562$, and the common reverse primer, corresponding to the CMV enhancer sequence included in the transgene construct. Among them, results of two amplifications are shown in Figure 4. P4, from $-46,680$, or P5, from $-45,797$, successfully produced the 1732-bp and 799-bp bands, respectively, in all $\mathrm{fad} 2$ samples, but not in the C57 samples. Sequencing and homology analysis of two fragments showed that the resulting sequence could be divided into three parts. The 3 '-end sequence was $100 \%$ identical to the initial sequence of the transgenic molecules. The middle sequence, including 327 nucleotides (from -3 to +324 in Figure 4C), showed $100 \%$ identity with the transgenic complementary sequence from 3580 to 3259 that linked the 3 '-end sequence with five additional nucleotides. The $5^{\prime}$-end sequence was $100 \%$ identical to the XC1 upstream sequence at position $87,462,177$, in 


\section{(A) 3'-integration site

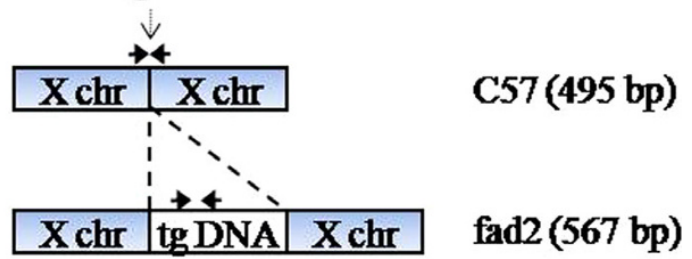 \\ (B)

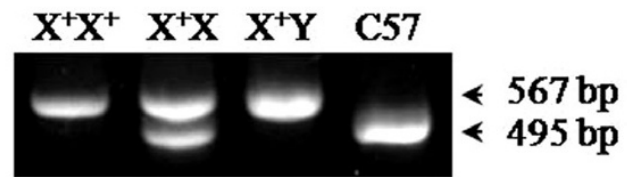 \\ Figure 3 Identity of homozygous or heterozygous fad 2 mice. (A) Schematic diagram of the primer positions indicating the fragments spanning the $3^{\prime}$ integration site in wild-type C57 or transgene-specific fragments in fad2 mice. (B) Site-specific primers used to identify fad2 homozygotes and heterozygotes. C57 samples had the 495-bp product only, fad2 males $\left(X^{+} Y\right)$ and homozygous females $\left(X^{+} X^{+}\right)$had the 567-bp transgene products only, and the heterozygous fad 2 females $\left(X^{+} X\right)$ had both bands together. $X^{+}$and $X$ represent the $X$ chromosome integrated with fad 2 transgene and wild-type $X$ chromosome, respectively.}

which three common nucleotides from -3 to $-1\left(5^{\prime}\right.$ TGT- $3^{\prime}$ ) were shared by the transgene and the X chromosome (Figure 4C).

Based on the $5^{\prime}$ and $3^{\prime}$ junction mapping results, we concluded that the entire 45,556-bp genomic region (from $87,462,177$ to $87,507,732$, in the XC1 region of chromosome $\mathrm{X}$ ) was successful replaced by the foreign DNA molecules during the process of random integration (Figure 5). For each junction, a very short homologous arm (3-7 bp) in the AT-rich domain presumably mediated the recombination of the transgene and the host genome (Figure 6).

\section{Transcription analysis}

PCR and sequencing analysis using primer pairs spanning the $5^{\prime}$ and $3^{\prime}$ transgenic sequences showed multiple copies of the transgene inserted into the same site of chromosome X (data not shown). To assess the transcriptional potential of $f a d 2$, total RNA from liver, kidney, brain, muscle, and heart tissues was analysed by RT-PCR. As shown in Figure 7, the amplification results from five primer sets corresponding to different regions revealed that no transcriptional signals were detected in the upstream region (-1123 to -977) of the $5^{\prime}$ integration site or the distal downstream region $(+859$ to +3069$)$ of the $3^{\prime}$ integration site in the C57 samples, while fad2 was expressed in all of the transgenic tissues (Figure $7 \mathrm{~B})$. In addition, the transcriptional signals of the $3^{\prime}$ flanking sequences in the $\mathrm{fad} 2$ mice, which extended at least 2299 but no more than 3069 nucleotides past the

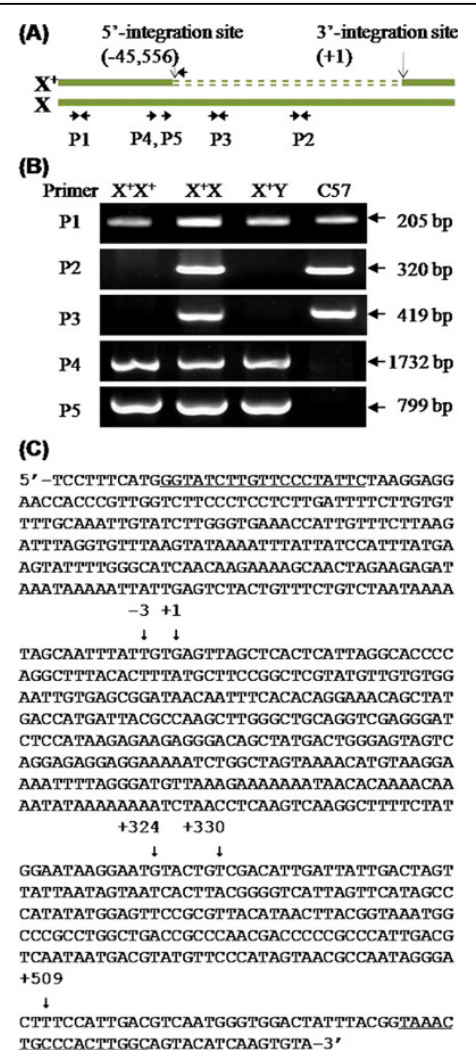

Figure 4 PCR analysis of the $\mathbf{5}^{\prime}$ integration site. (A) Schematic diagram of the approximate positions of five primer sets used for PCR analysis of the $5^{\prime}$ integration site. P1 $(-54,088$ to $-53,884)$, P2 $(-29,872$ to $-29,553)$, and P3 $(-44,562$ to $-44,144)$ primer pairs were designed according to the sequence upstream of nucleotide $87,507,732(+1)$, whereas the forward primers of P4 (from $-46,680$ ) and P5 (from $-45,797$ ) were designed corresponding to the $X$ sequence. The reverse primer (5'-gccaagtgggcagttta-3') corresponded to the CMV enhancer sequence included in the transgene construct. $X^{+}$represents the transgenic $X$. The doubledashed line represents the foreign DNA molecules. (B) Gel analysis of the PCR products amplified from the fad2 or C57 mice. The 205bp fragments using $\mathrm{P} 1$ primers were successfully amplified in $X^{+} X^{+}$, $X^{+} X, X^{+} Y$, or $C 57$ samples. The 320-bp fragments using P2 primers and the 419-bp fragments using P3 primers were only amplified in the $X^{+} X$ and C57, not in $X^{+} X^{+}$or $X^{+} Y$, samples. The 1732-bp fragment amplified by P4 primers and the 799-bp fragment amplified using P5 primers were present in all fad2, but not C57, mouse samples, and they were sequenced directly. (C) Nucleotide sequence of the P5 primer pair (underlined) and the $5^{\prime}$ integration region in fad 2 mice. Sequences from the $5^{\prime}$ initial nucleotide to +509 were determined by direct sequencing. The partial sequence from the $5^{\prime}$ initial nucleotide to -1 was $100 \%$ identical to the region upstream of the $87,462,177$ th nucleotide of the $X C 1$ region of the $X$ chromosome. The sequence from -3 to +509 showed $100 \%$ identity to the transgene sequence. A $5^{\prime}-$ TGT-3' sequence $(-3$ to -1$)$ was shared by the transgene and the $X$ chromosome as a very short homologous arm. Transgenic sequences were divided into two classes based on the presence of five additional nucleotides (TACTG). The sequence from -3 to +324 was $100 \%$ identical to the foreign complementary sequence (from 3580 to 3259). The sequence from +330 to the $3^{\prime}$ end was $100 \%$ identical to the $5^{\prime}$ initial sequence of the transgene. 


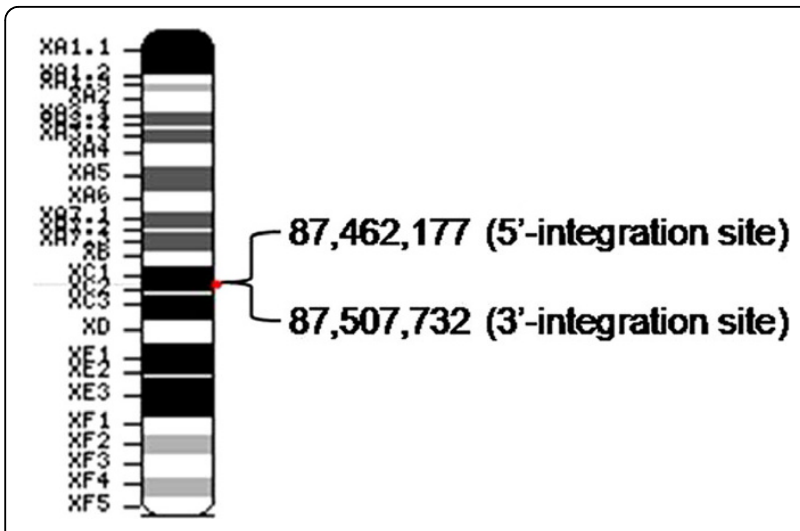

Figure $\mathbf{5}$ Transgene mapping on the $\mathbf{X}$ chromosome. The map of mouse chromosome $X$ shows that the entire 45,556 -bp region from $87,462,177$ to $87,507,732$ of XC1 was replaced by the foreign DNA during the process of random integration.

$3^{\prime}$ integration site, were detected by RT-PCR (Figure 7D-F).

\section{Transcription level of the $\mathrm{X}$-linked transgene}

To gauge the transcription level of the X-linked fad2 in females, we measured the expression of the foreign gene. Kidney, brain, and liver tissues from the $\mathrm{X}^{+} \mathrm{X}^{+}, \mathrm{X}$ ${ }^{+} \mathrm{X}, \mathrm{C} 57$ females, or $\mathrm{X}^{+} \mathrm{Y}$ males were analysed concurrently for reference. The real-time RT-PCR analysis showed that the foreign gene was expressed in all transgenic samples from the fad 2 females or males and that the transcription level in the $\mathrm{X}^{+} \mathrm{X}^{+}$females or $\mathrm{X}^{+} \mathrm{Y}$ males was about twice as high as in the $\mathrm{X}^{+} \mathrm{X}$ females ( $\mathrm{p}<0.05$, Figure 8$)$. The results suggest that the foreign fad2 behaved like an X-linked gene.

\section{5'-junction}

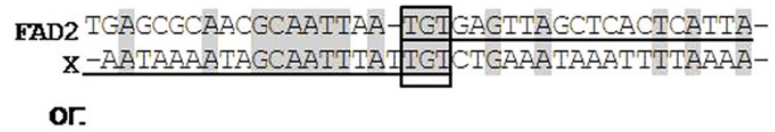

$$
\text { or. }
$$

FAD2 TGÄGGCAACGCAA-TTAITGT GAGTTAGCTCACTCATTA $\mathrm{x}$-AATAAAATAGCAATTTAT TGT CTGAAATAAATTTTAAAA-

\section{3'-junction}

FAD2 GATTATTGACT--AGTTZ TTAATACTAATCAATTACGGGGT$\mathrm{x}$--GTATTTACTTCAGAAOTTAATAGGT-TCCTTCTCCACTTA

Figure 6 Analysis of the sequences surrounding the junction sites. The junction sequences present in the fad 2 mice are underlined. Identical nucleotides in fad 2 and $X$ chromosome are indicated (grey shading). Three or seven identical nucleotides (boxed with grey shading) existed in the AT-rich domain, presumably corresponding to the common sequence of the recombination of transgene and host genome.

\section{Discussion}

Approximately $5-10 \%$ of the random DNA insertion events in transgenic animals are associated with recessive mutations or viable phenotypic alterations $[4,18]$. Integrated DNA may affect the endogenous genetic locus and result in inactivation of a given gene $[19,20]$. In some cases, transgene integration has been associated with host genome rearrangements, including duplications [21], translocation [22], and deletions [23-25]. The length of the deleted genome segments might be from $2-3 \mathrm{~kb}$ [23] to $22 \mathrm{~kb}$ [25]. In the current study, we successfully identified a foreign gene homologous inserted into the XC1 region by deletion of the entire 45,556-bp region of the endogenous DNA. Although the DNA deletion took place, all fad2 mice appeared normal, without any apparent lesions, and exhibited normal physiological activities and fertility. Sequence analysis revealed that no putative genes were positioned in the deleted 45,556-bp region in which one Gct4 phenotype allele of ovarian granulosa cell tumourigenesis 4 was involved (MGI ID: 98356). Previous studies involving juvenile granulosa cell tumours indicate that its susceptibility is an inherited, polygenic trait and that the X-linked Gct4 allele in the SJL mouse strain cause highfrequency, juvenile-type granulosa cell tumour development in females [26,27]. The fad2 gene inserted into the mouse genome could serve both as a mutagen and as a molecular tag to study the role of the Gct4 allele in juvenile-type granulosa cell tumour.

It is thought that linear DNA molecules injected into the pronucleus undergo rapid circularisation followed by random linearisation and concatemers formation by homologous recombination (Figure 9A, steps 1-3). Moreover, the injected molecules could then reconstitute and, most frequently, integrate as a head-to-tail array $[2,3,5,28,29]$, with a minor modification of nucleotide deletion or insertion at some ends $[7,11,30]$. In the present study, the multiple copies of the $f a d 2$ transgene molecules lost the $5^{\prime}$ initial GC dinucleotide, which was subsequently integrated into the $\mathrm{X}$ chromosome in a head-to-tail manner (Figure $2 \mathrm{C}$ ). In addition, a head-tohead fusion also occurred in the transgene, whereby one strand joined its partial complementary strand with five additional nucleotides at the same insertion site (Figure 4C, Figure 9B).

As far as we know, it is not clear exactly how the concatemers insert into the host genome. It was previously reported that the foreign histocompatibility class II $E_{\alpha}$ gene, injected into pronuclei, was homologous targeted into the transgenic mouse genome [31]. In most cases, it is predicted that the foreign DNA concatemers would finally integrate into the host genome randomly through imperfect sequence recognition via heterologous 


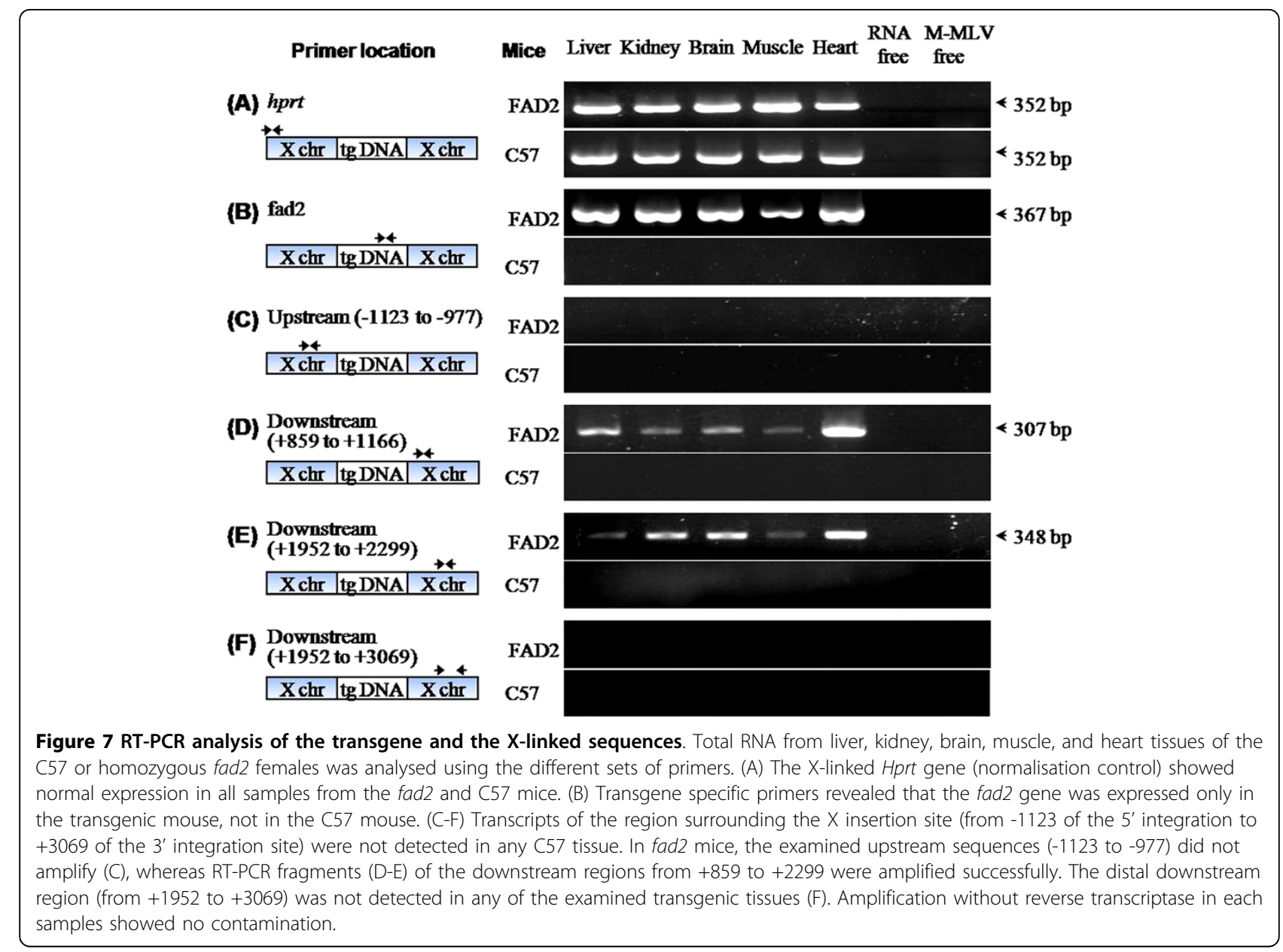

recombination [2,21]. In the current study, it is worth noting that the 3 -bp common sequence at the $5^{\prime}$ junction and the 7-bp common sequence at the 3 ' junction were shared by the $\mathrm{X}$ chromosome and foreign transgenic molecules. Furthermore, the homologous nucleotides in the $5^{\prime}$ junction would facilitate the recognition of two DNAs besides the 3-bp common sequence
(Figure 6, Figure 9B). Such small regions of identity (3-5 bp) have been observed in previous studies of nonhomologous recombination involving mouse transgenesis [11,29]. This suggests that the successful insertion of the transgene is mediated by these common sequences on both sides, which serve as anchors for the homologous illegitimate random integration (HIRI) but
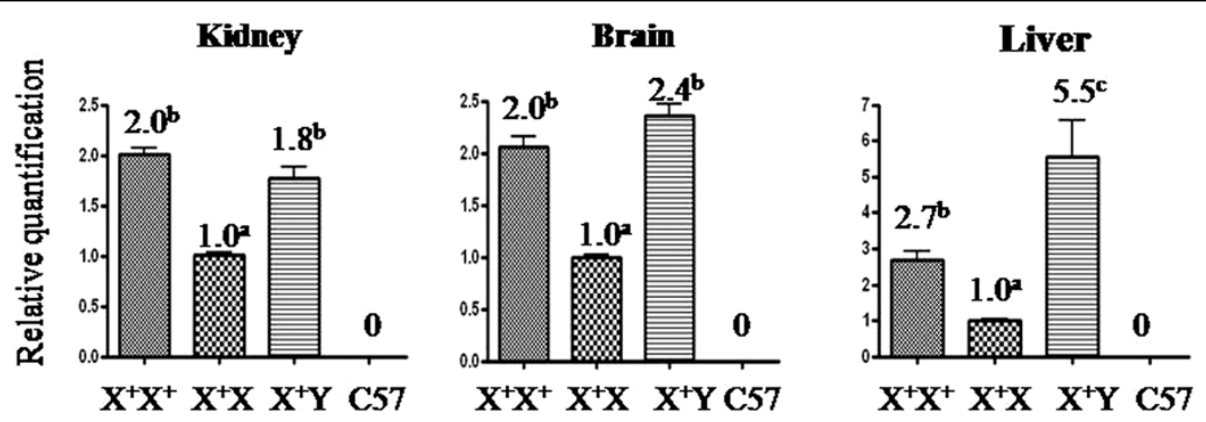

Figure $\mathbf{8}$ Relative expression of the $\mathbf{X}$-linked transgene. Sets of primers corresponding to fad2 or Gapdh were used for real-time RT-PCR analysis of the samples of transgenic or C57 kidney, brain, and liver. Expression data of fad2 were normalised to Gapdh expression and presented as the mean relative quantity (compared with $X^{+} X$ ), with error bars representing the SEM. Student's $t$-test was used to calculate $P$ values. Values with different superscripts were significantly different within same tissues $(P<0.05)$. 


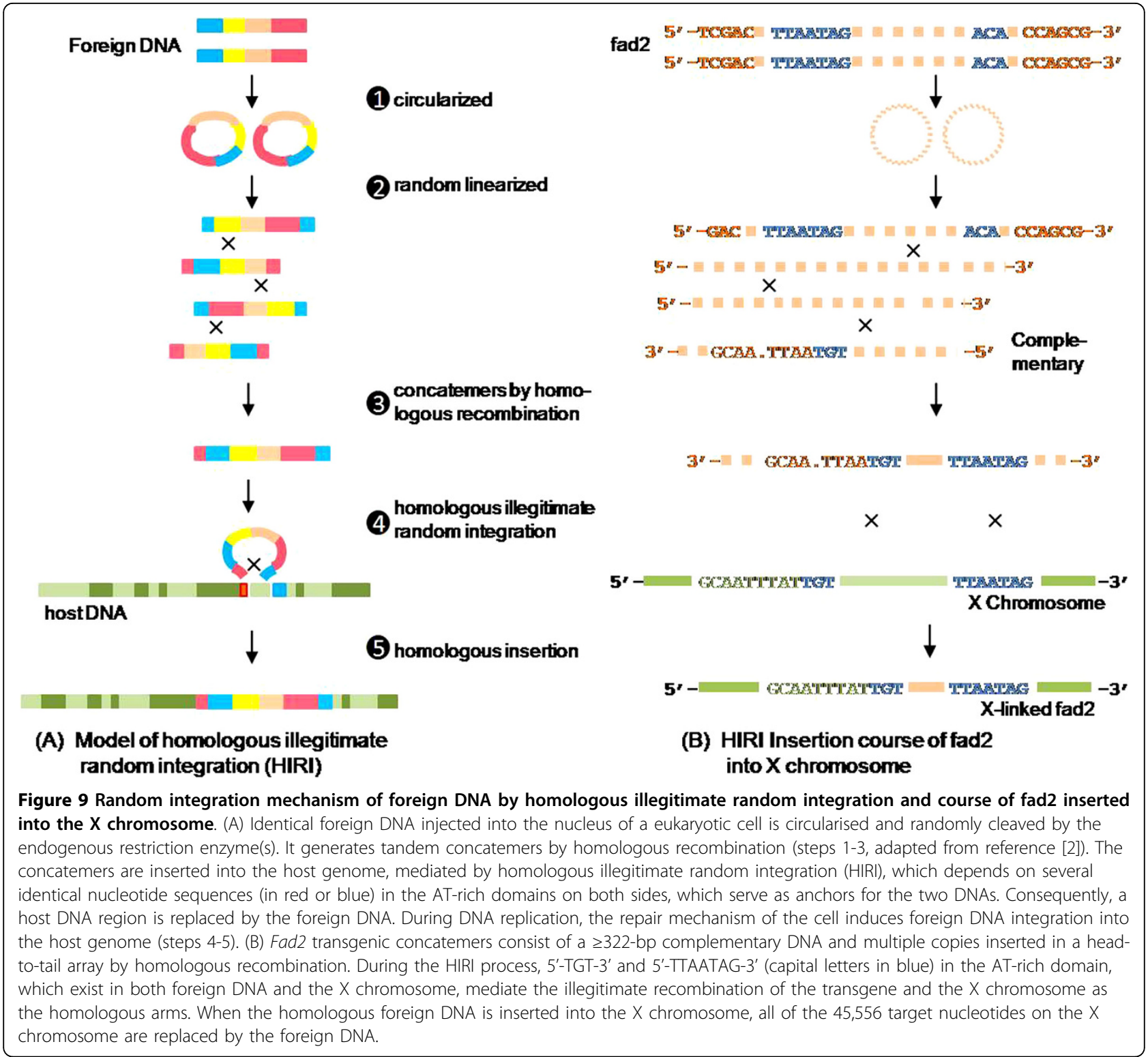

not heterologous recombination (Figure 9). Because the homologous arms are very short and consist only of several identical nucleotides, they can be easily positioned at various regions of the host genome. Therefore, it appears that the foreign DNA is randomly integrated into the host genome and the integration sites are unpredictable in transgenic animals [1,2]. After homologous recognition between the two DNA molecules, the insertion of a foreign DNA molecule into a genome is mediated by the DNA repair mechanisms of the cell $[2,6]$.

In addition to the common sequence, a palindromic sequence of $5^{\prime}$-ATTAAT- $3^{\prime}$ in both $5^{\prime}$ and $3^{\prime}$ junctions was found in the fad 2 sequence, but not in the $\mathrm{X}$ sequence (Figure 6). This sequence motif is required to induce a localised conversion in Streptococcus pneumoniae transformation [32]. The Ase I restriction endonuclease can recognise and cleave the sequence between the TT dinucleotide [33]. At this moment, we are not sure if an endonuclease plays a role in the HIRI process.

In mechanistic studies of natural transformation in prokaryotes, de Vries \& Wackernagel reported that short stretches of sequence identity (3-8 bp) between the kanamycin-resistant nptII ${ }^{+}$gene and the recipient DNA of transformed Acinetobacter facilitated the integration efficiency of foreign DNA into the prokaryotic genome by homology-facilitated illegitimate recombination using homologous regions ranging in length from 1 $\mathrm{kb}$ to $183 \mathrm{bp}$ [34]. Simultaneously, a consistent integration mechanism, mediated by one-side homologous 
substrates and containing identical 4-10 nucleotide sequences between the donor and recipient DNA, was also observed in the human pathogen Streptococcus pneumoniae transformed by recombinant lambda bacteriophage [35]. In addition, in Pseudomonas stutzeri a similar phenomenon was observed, in which part of the short anchor segments recombined into the host genome [36]. In eukaryotes, events of illegitimate integration whose homologous sequences are very short $(\leq 5 \mathrm{bp})$ are also found in mammalian cells [7,37], transgenic embryos [11], and mice [29]. Taken together, our observations suggest that the HIRI process is present in all organisms undergoing transformation/transgenesis (Figure 9A).

Interestingly, although the HIRI process in prokaryotes usually happens within segments of high GC content [34-36], our results reveal that it occurred in the AT-rich, not GC-rich, region between the two DNAs in eukaryotes (Figure 6). Similar results have been found in the transgenic embryo [11]. A systematic analysis of multiple illegitimate integration sites in somatic cells has found that in $93 \%$ of cases, these sites are only $10 \mathrm{bp}$ away from a potential topoisomerase I cleavage site. The association of topoisomerase I sites with runs of purines and AT-rich regions with the site of integration is also significant [12]. Purine tracts can adopt non-B-DNA conformations, which may be able to recombine; these sequences are found in the centromeres and may promote recombination of the satellite DNA [6]. These observations suggest that $\mathrm{AT}$-rich regions might be involved in the HIRI process.

Although in murine transformed 3T6 cells the poly (A) signal of the rabbit $\beta$-globin can direct efficient termination of polyomavirus DNA transcription through RNA polymerase II [38], in HeLa cells, in some cases, transcription of the foreign gene does not terminate thoroughly by the terminal signal of the $537-b p$ poly (A) full sequences [39]. The nucleotide sequence of the $3^{\prime}$ flanking region of the rabbit $\beta$-globin gene was transcribed 2447 bp past the poly (A) site. The transcription level in the M13 bacteriophage vector gradually declines, under control of its own enhancer and promoter [40]. In fad 2 mice, the transgene was expressed efficiently under the driven of the CMV enhancer and $\beta$-actin promoter (Figure 7, Figure 8) and its transcription had not been terminated thoroughly by the terminal signal of the rabbit $\beta$-globin gene poly (A) yet. RT-PCR results revealed that the $2.3 \mathrm{~kb}$ flanking regions post the 3 ' integration site was transcribed within all examined fad 2 tissues whereas these genomic regions kept silence in wild type (Figure 7D, 7E). Consistent with the previous study [40], these transcription level might gradually declines and the transcripts of the $3.0-\mathrm{kb}$ distal flanking regions of the 3 ' integration site had not been detected within all examined fad2 tissues (Figure 7F).

In mammals, dosage compensation takes place by silencing one of the two $\mathrm{X}$ chromosomes in female cells to achieve transcriptional balance with the XY male $[41,42]$. Transgenes carried on the $\mathrm{X}$ chromosome occasionally either escape the normal $\mathrm{X}$-inactivation process [43] or behave like an X-linked gene [44,45]. The cloning and characterisation of the host sequences flanking these inserts may contribute to our understanding of the molecular control mechanisms of chromosome pairing $[46,47]$ and mammalian X-inactivation $[44,45]$. As an X-linked transgene, the relative expression of fad2 was also examined in transgenic somatic tissues. The transgene expression behaved in a fashion similar to silence one of the two X chromosomes in female cells, at least within the tested female tissues. That was, only $50 \%$ of $\mathrm{X}^{+} \mathrm{X}$ cells expressed the fad 2 gene, whereas all $\mathrm{X}^{+} \mathrm{X}^{+}$female cells or $\mathrm{X}^{+} \mathrm{Y}$ male cells expressed the transgene. Subsequently, the relative amount expression of fad2 gene in the $\mathrm{X}^{+} \mathrm{X}$ organs was lower and estimated an approximately $50 \%$ amount of the $\mathrm{X}^{+} \mathrm{X}^{+}$female or $\mathrm{X}^{+} \mathrm{Y}$ male cells. These results suggest that the $\mathrm{XC1}$ region (from $87,462,177$ to $87,507,732$ ) is a locus amenable to the normal X-linked expression of foreign genes and can be used as a molecular tag to study the mechanism of $\mathrm{X}$ inactivation.

\section{Conclusions}

An X-linked transgenic mouse line is identified firstly in the current study. The real-time RT-PCR analysis indicates that the foreign $f a d 2$ gene is expressed in all transgenic samples from the fad 2 females and that the transcription level in the homozygous females is about twice as high as in the heterozygous females. That is, the transgene expression behaves in a fashion similar to silence one of the two X chromosomes in female cells, at least within the tested female tissues.

We successfully map the sequences of both sides of transgene-chromosome in fad 2 transgenic mice and identify that the $5^{\prime}$ and $3^{\prime}$ integration sites are located at base $87,462,177$ and $87,507,732$, respectively. PCR analysis reveals that the entire 45,556 -bp genome in the $\mathrm{XC1}$ region of chromosome $\mathrm{X}$ is deleted by the foreign DNA molecules during the process of random integration. The deleted 45,556-bp endogenous genomic region includes the ovarian granulosa cell tumourigenesis-4 allele.

For each junction sequence, a very short homologous arm (3-7 bp) in the AT-rich domain, for instance, TGT within the $5^{\prime}$ junction and TTAATAG within the $3^{\prime}$ junction, exists in both foreign fad2 gene and the X chromosome and presumably mediates the illegitimate 
recombination of two DNAs as the homologous arms. Based on the $5^{\prime}$ and $3^{\prime}$ junction mapping results, we predict that the foreign DNA insert into the host genome through a homologous illegitimate random integration (HIRI), which depends on several identical nucleotide sequences in the AT-rich domains on both sides.

\section{Methods}

Animals

All animals were maintained in a light-controlled room at $22^{\circ} \mathrm{C}$. All animal procedures were approved by the Committee for Experimental Animals of our university.

\section{Transgene construct}

An 1182-bp DNA sequence of the cotton fad2 open reading frame (GenBank accession No. X97016) was optimised and synthesised (Invitrogen) with a modification of codon usage for easier expression in mammals. The expression vector for microinjection contained the fad 2 gene driven by the cytomegalovirus (CMV) enhancer and the chicken $\beta$-actin promoter, as well as the rabbit $\beta$-globin poly (A) sequence at the 3 ' end. Transgenic mice were produced by pronuclear microinjection with the linear 3.6-kb transgenic cassettes digested by Sal I and BamH I.

\section{Transgene detection by nucleic acid analysis}

Genomic DNA was extracted from the tails of pups (3-4 weeks old) utilising the standard phenol-chloroform method, as previously described [1], and dissolved in TE buffer for nucleic acid analysis. The presence of the transgene was assayed by PCR amplification using transgene-specific primers (F: 5'-tacatcagcgacacaggcatc-3'; R: $5^{\prime}$-gtatttgtgagccagggcatt-3'). The amplified product was 567 bp long and spanned the fad2 gene sequence. PCR reactions contained $0.5-1.0 \mu \mathrm{g}$ of genomic DNA, 0.2 $\mathrm{mM}$ dNTPs, $0.4 \mu \mathrm{M}$ of primers, and 1 unit of Taq polymerase (Invitrogen) in $25 \mu \mathrm{l}$ of $1 \times$ reaction buffer. The reactions were performed at $94^{\circ} \mathrm{C}$ for $5 \mathrm{~min}$; 35 cycles of $94^{\circ} \mathrm{C}$ for $30 \mathrm{sec}, 58^{\circ} \mathrm{C}$ for $30 \mathrm{sec}$, and $72^{\circ} \mathrm{C}$ for $40 \mathrm{sec}$; and $72^{\circ} \mathrm{C}$ for $8 \mathrm{~min}$.

For Southern blotting analysis, $10 \mu \mathrm{g}$ of the genomic DNA was digested with EcoR I + Sca I for 12-16 hours, separated on $0.7 \%$ agarose gels overnight and blotted to Hybond-N+ membranes (Amersham, UK). The 1036-bp fragments from the pFAD2 plasmid produced by EcoR I + Sca I digestion were labelled with $\alpha-{ }^{32} \mathrm{P}-\mathrm{dCTP}$ (FuRui, China) using the Rediprime ${ }^{\mathrm{rm}} \mathrm{II}$ labelling kit (Amersham). The membranes were subsequently hybridised with the labelled probe according to standard protocols and exposed to X-ray film (Fuji Photo Film, Japan) for 24-48 hours at $-80^{\circ} \mathrm{C}$ with an intensifying screen to obtain an autoradiograph image.

\section{TAIL-PCR analysis of the $3^{\prime}$ integration site}

Three transgene specific primers (tgp1: $5^{\prime}$-ccttgagcatctgacttct-3'; tgp 2: 5'-aagccttgacttgaggttagat-3'; tgp3: $5^{\prime}$-gcttggcgtaatcatggtca- $\left.3^{\prime}\right)$ and an arbitrary degenerate primer (5'-ngtcgaswganawgaa-3') were used for TAILPCR amplification. The thermal cycling conditions are summarised in Table 1 . Briefly, the primary PCR reaction contained 0.5-1.0 $\mu \mathrm{g}$ genomic DNA, $1.5 \mathrm{mM}$ dNTPs, $0.2 \mu \mathrm{M}$ of tgp 1 primer, $2 \mu \mathrm{M}$ of the a.d. primer, and 1 unit of Taq polymerase in $20 \mu \mathrm{l}$ of $1 \times$ reaction buffer. In the secondary or tertiary amplification, $0.65 \mu \mathrm{l}$ of the first or secondary products, respectively, were used as templates and supplemented in the reaction. The products of tertiary TAIL-PCR reaction were separated on a $1.5 \%$ agarose gel. A single band in each mouse sample was gel purified with the TIANgel Midi Purification Kit (Tiangen, China) and sequenced directly. The resultant sequences were analysed using online BLAST from the database of Mus musculus genomic DNA http://www.ncbi.nlm.nih.gov.

\section{PCR analysis of transgene homozygotes and heterozygotes}

Genomic DNA from the tails of C57 females (wild type), fad 2 males $\left(\mathrm{X}^{+} \mathrm{Y}\right)$, or homozygous $\left(\mathrm{X}^{+} \mathrm{X}^{+}\right)$or heterozygous $\left(\mathrm{X}^{+} \mathrm{X}\right)$ fad2 females was used to determine their homozygosity or heterozygosity. In brief, genome-specific primers for 495-bp fragments (F: $5^{\prime}$-agtctgcaattttagatcctc-3'; R: 5'-gaagtttcagcagcaacac-3') and transgenespecific primers for 567-bp fragments were added to the same PCR reaction and amplified together. The PCR cycling parameters were as follows: $95^{\circ} \mathrm{C}$ for $5 \mathrm{~min} ; 35$ cycles of $94^{\circ} \mathrm{C}$ for $30 \mathrm{sec}, 56^{\circ} \mathrm{C}$ for $30 \mathrm{sec}$, and $72^{\circ} \mathrm{C}$ for $60 \mathrm{sec}$; and $72^{\circ} \mathrm{C}$ for $10 \mathrm{~min}$.

\section{PCR analysis of the $5^{\prime}$ integration site}

Based on the results of the $3^{\prime}$ integration analysis, each DNA sample of $\mathrm{X}^{+} \mathrm{Y}, \mathrm{X}^{+} \mathrm{X}^{+}, \mathrm{X}^{+} \mathrm{X}$ or C57 mice was amplified by the following primer sets: P1 (F: $5^{\prime}-$ cgctcagtcagtcaccag-3'; R: 5' -ggacttcgattaccgttt-3'), P2 (F: $5^{\prime}$-catcagtgctccattct-3'; R: 5'-aacaggcttgtggtcatt- $\left.3^{\prime}\right)$, and P3 (F: 5'-aactcaagggacaccaca-3'; R: 5'-aatccgcatgaataccag$\left.3^{\prime}\right)$. The three primer pairs corresponded to the upstream 3 ' integration regions from $-54,088$ to $-53,884$, $-29,872$ to $-29,553$, and $-44,562$ to $-44,144$, respectively. PCR amplification was performed as follows: $95^{\circ} \mathrm{C}$ for 5 min; 30 cycles of $94^{\circ} \mathrm{C}$ for $30 \mathrm{sec}, 57.6^{\circ} \mathrm{C}$ for $30 \mathrm{sec}$, and $72^{\circ} \mathrm{C}$ for $60 \mathrm{sec}$; and a final extension at $72^{\circ} \mathrm{C}$ for 10 min. P4 forward primer at $-46,680\left(5^{\prime}\right.$-agcctagtggtacatcat-3') or P5 forward primer at $-45,797$ (5'ggtatcttgttccctattc- $3^{\prime}$ ) of the $3^{\prime}$ integration upstream region was used along with the common reverse primer (5'-gccaagtgggcagttta-3'), corresponding to the CMV 
Table 1 Cycle Conditions used for TAIL-PCR

\begin{tabular}{|c|c|c|c|}
\hline Reaction & $\begin{array}{l}\text { Program } \\
\text { no. }\end{array}$ & $\begin{array}{l}\text { Cycle } \\
\text { no. }\end{array}$ & Thermal condition \\
\hline \multirow[t]{4}{*}{ Primary (tgp1/ad) } & 1 & 1 & $95^{\circ} \mathrm{C}, 5 \mathrm{~min}$ \\
\hline & 2 & 10 & $94^{\circ} \mathrm{C}, 10 \mathrm{sec} ; 63^{\circ} \mathrm{C}, 30 \mathrm{sec} ; 72^{\circ} \mathrm{C}, 3 \mathrm{~min}$ \\
\hline & 3 & 1 & $94^{\circ} \mathrm{C}, 10 \mathrm{sec} ; 25^{\circ} \mathrm{C}, 3 \mathrm{~min} ; 72^{\circ} \mathrm{C}, 2.5 \mathrm{~min}$ \\
\hline & 4 & 15 & $\begin{array}{l}94^{\circ} \mathrm{C}, 10 \mathrm{sec} ; 63^{\circ} \mathrm{C}, 3 \mathrm{~min} ; 72^{\circ} \mathrm{C}, 2.5 \mathrm{~min} ; 94^{\circ} \mathrm{C}, 10 \mathrm{sec} ; 63^{\circ} \mathrm{C}, 3 \mathrm{~min} ; 72^{\circ} \mathrm{C}, 2.5 \mathrm{~min} ; 94^{\circ} \mathrm{C}, 10 \mathrm{sec} ; 44^{\circ} \mathrm{C}, 1 \mathrm{~min} \\
72^{\circ} \mathrm{C}, 2.5 \mathrm{~min}\end{array}$ \\
\hline \multirow[t]{2}{*}{ Secondary (tgp2/ad) } & 5 & 1 & $95^{\circ} \mathrm{C}, 5 \mathrm{~min}$ \\
\hline & 6 & 15 & $\begin{array}{l}94^{\circ} \mathrm{C}, 10 \mathrm{sec} ; 65^{\circ} \mathrm{C}, 3 \mathrm{~min} ; 72^{\circ} \mathrm{C}, 2.5 \mathrm{~min} ; 94^{\circ} \mathrm{C}, 10 \mathrm{sec} ; 65^{\circ} \mathrm{C}, 3 \mathrm{~min} ; 72^{\circ} \mathrm{C}, 2.5 \mathrm{~min} ; 94^{\circ} \mathrm{C}, 10 \mathrm{sec} ; 44^{\circ} \mathrm{C}, 1 \mathrm{~min} \\
72^{\circ} \mathrm{C}, 2.5 \mathrm{~min}\end{array}$ \\
\hline \multirow[t]{2}{*}{ Tertiary (tgp3/ad) } & 5 & 1 & $95^{\circ} \mathrm{C}, 5 \mathrm{~min}$ \\
\hline & 6 & 15 & $\begin{array}{l}94^{\circ} \mathrm{C}, 10 \mathrm{sec} ; 65^{\circ} \mathrm{C}, 3 \mathrm{~min} ; 72^{\circ} \mathrm{C}, 2.5 \mathrm{~min} ; 94^{\circ} \mathrm{C}, 10 \mathrm{sec} ; 65^{\circ} \mathrm{C}, 3 \mathrm{~min} ; 72^{\circ} \mathrm{C}, 2.5 \mathrm{~min} ; 94^{\circ} \mathrm{C}, 10 \mathrm{sec} ; 44^{\circ} \mathrm{C}, 1 \mathrm{~min} \\
72^{\circ} \mathrm{C}, 2.5 \mathrm{~min}\end{array}$ \\
\hline
\end{tabular}

molecules needed to amplify the relevant junction sequences. P4 amplification was performed as follows: $95^{\circ} \mathrm{C}$ for $5 \mathrm{~min} ; 40$ cycles of $94^{\circ} \mathrm{C}$ for $30 \mathrm{sec}, 56.4^{\circ} \mathrm{C}$ for $30 \mathrm{sec}$, and $72^{\circ} \mathrm{C}$ for $2 \mathrm{~min}$; and a final extension at $72^{\circ}$ $\mathrm{C}$ for $8 \mathrm{~min}$. P5 conditions were: 40 cycles of $94^{\circ} \mathrm{C}$ for $30 \mathrm{sec}, 58^{\circ} \mathrm{C}$ for $30 \mathrm{sec}$, and $72^{\circ} \mathrm{C}$ for $60 \mathrm{sec}$. P4 and P5 products were sequenced directly.

\section{RT-PCR}

Total RNA was extracted from the fresh tissues (liver, kidney, brain, muscle and heart) of fad2 or C57 females with TRIzol Reagent (Tiangen) and treated with RNasefree DNase I (TaKaRa) to remove the remaining genomic DNA prior to RT-PCR. Purified RNA $(0.5 \mu \mathrm{g})$ was used for first-strand cDNA synthesis. Reverse transcription was performed using M-MLV reverse transcriptase (Promega) with oligo-dT primers according to the manufacturer's instructions. Reactions in the absence of reverse transcriptase were also included for each RNA sample to check for DNA contamination. The resultant cDNA was used in PCR amplification to investigate the level of gene transcription. Besides the transcriptional amplification of the $f a d 2$ gene using transgene-specific primers (F: 5'-tacatcagcgacacaggcatc-3'; R: 5' -gtattgtgagccagggcatt-3'), RT-PCR was also used to investigate the expression of the $5^{\prime}$ integration upstream region from -1123 to -977 (F: 5' -agcctagtggtacatcat-3'; R: 5'ttggcctacattagacat- $\left.3^{\prime}\right)$ and the $3^{\prime}$ integration downstream region from +859 to +1166 (F: $5^{\prime}$-attaggtcccctcagtgtc- $3^{\prime}$; R: $5^{\prime}$-ctcatctcagaaatcattaccc-3'), +1952 to +2299 (F: 5'tgacagagcgtctaagga-3'; R: 5'-gaggtaacccaatcacaaa-3'), and +1952 to +3069 (F: 5' - tgacagagcgtctaagga-3'; R: 5' cagaacaccaatggcttg- $\left.3^{\prime}\right)$. The annealing temperature was $55^{\circ} \mathrm{C}, 55^{\circ} \mathrm{C}, 56^{\circ} \mathrm{C}$, or $57.6^{\circ} \mathrm{C}$, respectively. Concurrently, the 352-bp control fragments of the Hprt gene (F: $5^{\prime}$ cctgctggattacattaaagcactg-3'; R: 5'-gtcaagggcatatccaacaacaaac- $\left.3^{\prime}\right)$ were amplified as follows: $95^{\circ} \mathrm{C}$ for $5 \mathrm{~min}$; 35 cycles of $94^{\circ} \mathrm{C}$ for $30 \mathrm{sec}, 55^{\circ} \mathrm{C}$ for $30 \mathrm{sec}$, and $72^{\circ} \mathrm{C}$ for $60 \mathrm{sec}$; and final extension at $72^{\circ} \mathrm{C}$ for $8 \mathrm{~min}$.

\section{Real-time RT-PCR}

Real-time RT-PCR was used to determine the relative expression of the fad 2 transgene (F: $5^{\prime}$-ttccacaacatcaccgacac-3'; R: 5'-ctccacgtacaggcactcc-3') in transgenic kidney, brain and liver tissues. Gapdh (F: 5'-gaacatcatcctgcatcc-3'; R: $5^{\prime}$-ccagtgagcttcccgttca-3') was amplified concurrently as an endogenous control. Each sample from $\mathrm{X}^{+} \mathrm{X}^{+}, \mathrm{X}^{+} \mathrm{X}$, C57 females or $\mathrm{X}^{+} \mathrm{Y}$ males was amplified in triplicate. Real-time PCR reactions were performed on an ABI Prism 7500 sequence detection system (Applied Biosystems) using $\mathrm{SYBR}^{\oplus}$ Premix Ex $\mathrm{Taq}^{\mathrm{Tm}}$ II kits (TaKaRa), following the manufacturer's protocol. The thermocycling protocol was as follows: $95^{\circ} \mathrm{C}$ for $30 \mathrm{sec}, 40$ cycles of $95^{\circ} \mathrm{C}$ for $5 \mathrm{sec}$ and $60^{\circ} \mathrm{C}$ for $34 \mathrm{sec}$. Expression of the fad 2 gene was examined relative to the internal control gene using the 2 $(-\Delta \Delta C(T))$ method.

\section{Statistical analysis}

RNAs from two mice of each genotype were processed and amplified by real-time RT-PCR, with at least three measurements per animal. All values are presented as means \pm SEM. A ratio was considered significant if the mean $t$-test $P$ value was less than or equal to 0.05 for each of the samples. Prism 4 for Windows (GraphPad) was used for all calculations.

\section{Acknowledgements}

The work was supported by Natural Sciences of Foundation in China (30571332), and 973 Project of China (2004CB117500). We thank Professor Sheng Cui for real-time RT-PCR and Professor Yaofeng Zhao for critic discussion.

\section{Author details}

${ }^{1}$ State Key Laboratory for Agrobiotechnology, College of Biological Sciences, China Agricultural University, Beijing 100193, China. ${ }^{2}$ College of Animal Sciences \& Technologies, China Agricultural University, Beijing 100193, China. 


\section{Authors' contributions}

BY carried out the molecular studies and data analysis. DL participated in the design of the study and assisted in writing the manuscript. KG conceived of the study, and participated in its design and coordination and wrote the manuscript. All authors read and approved the final manuscript.

Received: 21 April 2010 Accepted: 13 August 2010

Published: 13 August 2010

\section{References}

1. Nagy A, Gertsenstein M, Vintersten K, Behringer R: Manipulating the Mouse Embryo: A Laboratory Manual New York: Cold Spring Harbor Laboratory Press, 32003

2. Houdebine L-M: Animal Transgenesis and Cloning John Wiley \& Sons Ltd, 1 2003.

3. Brinster RL, Chen HY, Trumbauer M, Senear AW, Warren R, Palmiter RD: Somatic expression of herpes thymidine kinase in mice following injection of a fusion gene into eggs. Cell 1981, 27:223-231.

4. Jaenisch R: Transgenic animals. Science 1988, 240:1468-1474.

5. Bishop JO, Smith P: Mechanism of chromosomal integration of microinjected DNA. Mol Biol Med 1989, 6:283-298.

6. Wurtele H, Little KC, Chartrand P: Illegitimate DNA integration in mammalian cells. Gene Ther 2003, 10:1791-1799.

7. Merrihew RV, Marburger K, Pennington SL, Roth DB, Wilson JH: Highfrequency illegitimate integration of transfected DNA at preintegrated target sites in a mammalian genome. Mol Cell Biol 1996, 16:10-18.

8. Rijkers T, Peetz A, Ruther U: Insertional mutagenesis in transgenic mice. Transgenic Res 1994, 3:203-215.

9. Milot E, Belmaaza A, Wallenburg JC, Gusew N, Bradley WE, Chartrand P: Chromosomal illegitimate recombination in mammalian cells is associated with intrinsically bent DNA elements. EMBO J 1992, 11:5063-5070

10. Kusakabe T, Sugimoto Y, Maeda T, Nakajima Y, Miyano M, Nishikawa J, et al: Linearization and integration of DNA into cells preferentially occurs at intrinsically curved regions from human LINE-1 repetitive element. Gene 2001, 274:271-281.

11. Hamada T, Sasaki H, Seki R, Sakaki Y: Mechanism of chromosomal integration of transgenes in microinjected mouse eggs: sequence analysis of genome-transgene and transgene-transgene junctions at two loci. Gene 1993, 128:197-202.

12. Konopka AK: Compilation of DNA strand exchange sites for nonhomologous recombination in somatic cells. Nucl Acids Res 1988, 16:1739-1758

13. Liu YG, Whittier RF: Thermal asymmetric interlaced PCR: automatable amplification and sequencing of insert end fragments from P1 and YAC clones for chromosome walking. Genomics 1995, 25:674-681.

14. Liu YG, Mitsukawa N, Oosumi T, Whittier RF: Efficient isolation and mapping of Arabidopsis thaliana T-DNA insert junctions by thermal asymmetric interlaced PCR. Plant J 1995, 8:457-463.

15. Yanaka N, Kobayashi K, Wakimoto K, Yamada E, Imahie H, Imai Y, et al: Insertional Mutation of the Murine Kisimo Locus Caused a Defect in Spermatogenesis. Journal of Biological Chemistry 2000, 275:14791-14794.

16. Babushok DV, Ostertag EM, Courtney CE, Choi JM, Kazazian HH Jr: L1 integration in a transgenic mouse model. Genome Res 2006, 16:240-250

17. Pillai MM, Venkataraman GM, Kosak S, Torok-Storb B: Integration site analysis in transgenic mice by thermal asymmetric interlaced (TAIL)-PCR: segregating multiple-integrant founder lines and determining zygosity. Transgenic Res 2008, 17:749-754

18. Palmiter RD, Brinster RL: Germ-line transformation of mice. Annu Rev Genet 1986, 20:465-499.

19. Woychik RP, Stewart TA, Davis LG, D'Eustachio P, Leder P: An inherited limb deformity created by insertional mutagenesis in a transgenic mouse. Nature 1985, 318:36-40.

20. Weiher H, Noda T, Gray DA, Sharpe AH, Jaenisch R: Transgenic mouse model of kidney disease: insertional inactivation of ubiquitously expressed gene leads to nephrotic syndrome. Cell 1990, 62:425-434.

21. Wilkie TM, Palmiter RD: Analysis of the integrant in MyK-103 transgenic mice in which males fail to transmit the integrant. Mol Cell Biol 1987 7:1646-1655.
22. Mahon KA, Overbeek PA, Westphal H: Prenatal Lethality in a Transgenic Mouse Line is the Result of a Chromosomal Translocation. PNAS 1988, 85:1165-1168.

23. Radice $\mathrm{G}$, Lee JJ, Costantini F: $\mathrm{H}$ beta 58 , an insertional mutation affecting early postimplantation development of the mouse embryo. Development 1991, 111:801-811.

24. Covarrubias L, Nishida Y, Mintz B: Early Postimplantation Embryo Lethality due to DNA Rearrangements in a Transgenic Mouse Strain. PNAS 1986, 83:6020-6024.

25. Mark WH, Signorelli K, Blum M, Kwee L, Lacy E: Genomic structure of the locus associated with an insertional mutation in line 4 transgenic mice. Genomics 1992, 13:159-166.

26. Beamer WG, Shultz KL, Tennent BJ, Nadeau JH, Churchill GA, Eicher EM: Multigenic and Imprinting Control of Ovarian Granulosa Cell Tumorigenesis in Mice. Cancer Res 1998, 58:3694-3699.

27. Dorward AM, Shultz KL, Ackert-Bicknell CL, Eicher EM, Beamer WG: HighResolution Genetic Map of X-Linked Juvenile-Type Granulosa Cell Tumor Susceptibility Genes in Mouse. Cancer Res 2003, 63:8197-8202

28. Costantini F, Lacy E: Introduction of a rabbit beta-globin gene into the mouse germ line. Nature 1981, 294:92-94

29. Allen MJ, Jeffreys AJ, Surani MA, Barton S, LNorris M, Collick A: Tandemly repeated transgenes of the human minisatellite MS32 (D1S8), with novel mouse gamma satellite integration. Nucl Acids Res 1994, 22:2976-2981.

30. Rohan RM, King D, Frels WI: Direct sequencing of PCR-amplified junction fragments from tandemly repeated transgenes. Nucl Acids Res 1990, 18:6089-6095.

31. Brinster RL, Braun RE, Lo D, Avarbock MR, Oram F, Palmiter RD: Targeted Correction of a Major Histocompatibility Class II Ealpha Gene by DNA Microinjected into Mouse Eggs. PNAS 1989, 86:7087-7091.

32. Garcia P, Gasc AM, Kyriakidis X, Baty D, Sicard M: DNA sequences required to induce localized conversion in Streptococcus pneumoniae transformation. Mol Gen Genet 1988, 214:509-513.

33. Polisson C, Morgan RD: Asel, a restriction endonuclease from Aquaspirillum serpens which recognizes 5'AT TAAT3'. Nucl Acids Res 1988, 16:10365.

34. de Vries J, Wackernagel W: Integration of foreign DNA during natural transformation of Acinetobacter sp. by homology-facilitated illegitimate recombination. Proceedings of the National Academy of Sciences of the United States of America 2002, 99:2094-2099.

35. Prudhomme M, Libante V, Claverys JP: Homologous recombination at the border: Insertion-deletions and the trapping of foreign DNA in Streptococcus pneumoniae. Proceedings of the National Academy of Sciences of the United States of America 2002, 99:2100-2105.

36. Meier $P$, Wackernagel $W$ : Mechanisms of homology-facilitated illegitimate recombination for foreign DNA acquisition in transformable Pseudomonas stutzeri. Mol Microbiol 2003, 48:1107-1118.

37. Sakagami K, Tokinaga Y, Yoshikura H, Kobayashi I: Homology-associated nonhomologous recombination in mammalian gene targeting. Proceedings of the National Academy of Sciences of the United States of America 1994, 91:8527-8531.

38. Lanoix J, Acheson NH: A rabbit beta-globin polyadenylation signal directs efficient termination of transcription of polyomavirus DNA. EMBO J 1988, 7:2515-2522

39. Levitt N, Briggs D, Gil A, Proudfoot NJ: Definition of An Efficient Synthetic Poly(A) Site. Genes \& Development 1989, 3:1019-1025

40. Rohrbaugh ML, Johnson JE, James MD, Hardison RC: Transcription unit of the rabbit beta 1 globin gene. Mol Cell Biol 1985, 5:147-160.

41. Lyon MF: Gene action in the X-chromosome of the mouse (Mus musculus L.). Nature 1961, 190:372-373.

42. Chow J, Heard $\mathrm{E}: \mathrm{X}$ inactivation and the complexities of silencing a sex chromosome. Curr Opin Cell Biol 2009, 21:359-366.

43. Goldman MA, Stokes KR, Idzerda RL, McKnight GS, Hammer RE, Brinster RL, et al: A chicken transferrin gene in transgenic mice escapes $X$ chromosome inactivation. Science 1987, 236:593-595.

44. Krumlauf R, Chapman VM, Hammer RE, Brinster R, Tilghman SM: Differential expression of alpha-fetoprotein genes on the inactive $X$ chromosome in extraembryonic and somatic tissues of a transgenic mouse line. Nature 1986, 319:224-226 
45. Hadjantonakis AK, Cox LL, Tam PP, Nagy A: An X-linked GFP transgene reveals unexpected paternal $X$-chromosome activity in trophoblastic giant cells of the mouse placenta. Genesis 2001, 29:133-140.

46. Soriano P, Keitges EA, Schorderet DF, Harbers K, Gartler SM, Jaenisch R: High Rate of Recombination and Double Crossovers in the Mouse Pseudoautosomal Region during Male Meiosis. PNAS 1987, 84:7218-7220.

47. Harbers K, Soriano P, Muller U, Jaenisch R: High frequency of unequal recombination in pseudoautosomal region shown by proviral insertion in transgenic mouse. Nature 1986, 324:682-685.

doi:10.1186/1471-2199-11-58

Cite this article as: Yan et al:: Homologous illegitimate random integration of foreign DNA into the $\mathrm{X}$ chromosome of a transgenic mouse line. BMC Molecular Biology 2010 11:58.

\section{Submit your next manuscript to BioMed Central} and take full advantage of:

- Convenient online submission

- Thorough peer review

- No space constraints or color figure charges

- Immediate publication on acceptance

- Inclusion in PubMed, CAS, Scopus and Google Scholar

- Research which is freely available for redistribution

Submit your manuscript at www.biomedcentral.com/submit
C Biomed Central 